\title{
Brain Endothelial Cell Infection in Children with Acute Fatal Measles
}

\author{
Lisa M. Esolen, * Kiyomi Takahashi, ${ }^{\ddagger}$ Richard T. Johnson, ${ }^{\ddagger}$ Abraham Vaisberg, ${ }^{\$}$ Thomas R. Moench, * \\ Steven L. Wesselingh, ${ }^{\star *}$ and Diane E. Griffin ${ }^{\star *} \|$ \\ *Department of Medicine, Division of Infectious Diseases, ${ }^{\ddagger}$ Department of Neurology, The Johns Hopkins University School of \\ Medicine, and "Department of Molecular Microbiology and Immunology, The Johns Hopkins School of Hygiene and Public Health, \\ Baltimore, Maryland 21205; and ${ }^{\S}$ Universidad Peruana Cayetano Heredia, Lima, Peru
}

\begin{abstract}
Neurologic diseases are important complications of measles. The role of virus infection of the central nervous system as well as the route of virus entry has been unclear. Five autopsied cases of individuals who died with severe acute measles 3-10 d after the onset of the rash were studied for evidence of viral involvement of the central nervous system. In all cases, in situ hybridization and RT-PCR in situ hybridization techniques showed endothelial cell infection. Immunoperoxidase staining with an anti-ferritin antibody revealed a reactive microgliosis. These data suggest that endothelial cells in the brain are frequently infected during acute fatal measles. This site of infection may provide a portal of entry for virus in individuals who subsequently develop subacute sclerosing panencephalitis or measles inclusion body encephalitis and a target for immunologic reactions in postmeasles encephalomyelitis. (J. Clin. Invest. 1995. 96:24782481.) Key words: encephalomyelitis • measles virus • subacute sclerosing panencephalitis $\cdot$ microglia $\cdot$ blood-brain barrier
\end{abstract}

\section{Introduction}

Many viruses infect endothelial cells, and such infection is often an important component of the pathogenesis of those diseases (1-10). Measles virus can infect endothelial cells in culture (10) and has been visualized in vascular endothelial cells of the thymus, liver and lymph nodes in cases of acute fatal measles (11). Infection of the central nervous system (CNS) ${ }^{1}$ during acute disease has not been described although measles virus has been associated with various CNS sequelae.

Measles virus causes predominantly two types of CNS complications. Subacute sclerosing panencephalitis (SSPE) is a rare complication which occurs many years after acute measles and is associated with viral infection of neuronal and glial cells.

Address correspondence to Diane E. Griffin, MD, PhD, Molecular Microbiology \& Immunology, Johns Hopkins University School of Public Health, 615 N. Wolfe St., Baltimore, MD. 21205. Phone: 410-955-3726; FAX: 410-955-0105.

Received for publication 8 May 1995 and accepted in revised form 6 July 1995.

1. Abbreviations used in this paper: CNS, central nervous system; GFAP, glial fibrillary acidic protein; RT-PCR, reverse transcriptasePCR; SSPE, subacute sclerosing panencephalitis.

J. Clin. Invest.

(C) The American Society for Clinical Investigation, Inc.

0021-9738/95/11/2478/04 \$2.00

Volume 96, November 1995, 2478-2481
While virus cannot readily be cultured from the affected tissues of these patients, viral antigens and nucleic acids are seen by immunohistochemistry and in situ hybridization, and paramyxovirus-like particles are demonstrable on electron microscopy $(12,13)$. A somewhat similar progressive CNS disease, measles inclusion body encephalitis, occurs occasionally in immunosuppressed children $(14,15)$. The time and route of virus entry into the CNS, for either of these diseases, is unknown. Postmeasles encephalomyelitis, the most frequent CNS complication of measles, is a demyelinating neurologic disease, thought to be autoimmune in nature, that occurs at the time of acute measles (11, 16-19).

Recently, we have developed more sensitive techniques for the localization of measles virus by in situ hybridization and RT-PCR in situ hybridization, and have examined the brains of individuals dying with acute measles. We have found vascular endothelial cells in the brain to be infected frequently during acute fatal disease. This infection may provide a route for virus entry and could facilitate the development of postmeasles encephalomyelitis.

\section{Methods}

Autopsy tissue. Autopsy material from five patients with acute fatal measles cases was prospectively acquired at Hospital del Niño, Lima, Peru, between 1983 and 1985. These patients died of pneumonia between 3 and $10 \mathrm{~d}$ after the onset of the rash. The age range was 6 mo to $5 \mathrm{yr}$. Table I describes the patient characteristics. Control brains were obtained at the Johns Hopkins Hospital from three patients with AIDS, heart failure, and an encephalitis of unknown etiology. The material from Johns Hopkins had been formalin-fixed and paraffin-embedded in routine fashion, and the Peruvian material was fixed for $18 \mathrm{~h}$ in paraformaldehyde-lysine-periodate-glutaraldehyde, washed in buffer, and embedded in paraplast. Antigen detection studies and in situ hybridization with an ${ }^{35} \mathrm{~S}$-labeled RNA probe of these cases have previously been reported (11).

In situ hybridization. Sections were deparaffinized in fresh xylene for $10 \mathrm{~min}$, rinsed twice in $100 \%$ ethanol for $10 \mathrm{~min}$, then allowed to air dry. Sections were rehydrated through graded ethanol dilutions, then washed three times in $1 \times$ PBS for $5 \mathrm{~min} .300 \mu \mathrm{l}$ of prehybridization solution (deionized formamide, $5 \mathrm{ml} ; 20 \times \mathrm{SSC}, 2 \mathrm{ml} ; 50 \times$ Denhardt's solution, $0.2 \mathrm{ml}$; denatured herring sperm DNA [10 mg/ml], $0.5 \mathrm{ml}$; yeast transfer RNA [10 mg/ml ], $0.25 \mathrm{ml} ; 50 \%$ dextran sulfate, $2 \mathrm{ml}$; final volume of $9.95 \mathrm{ml}$ ) was added to each slide, and slides were incubated in a moist chamber for $1 \mathrm{~h}$. After prehybridization, slides were placed in $2 \times$ SSC briefly then $30 \mu$ l hybridization solution was applied per slide. Hybridization solution was prepared by placing $\sim 35$ pmoles of labeled oligonucleotide (anti-sense fusion protein probe, $5^{\prime}$ to 3': AGGACTCTGTGTCGACGTGAGTTATCCGGC; sense fusion protein probe, $5^{\prime}$ to $3^{\prime}$ : CCCGGATAACTCACGTCGACACAGAGTCCT) into $1 \mathrm{ml}$ of prehybridization solution. Oligonucleotide was labeled as follows. From a DNA tailing kit (Boehringer-Mannheim, Indianapolis, IN), $5 \mu$ l of $5 \times$ potassium cacodylate in Tris buffer ( $\mathrm{pH} 6.6$ ), $\mathrm{CoCl}_{2}$ ( $6 \mu$ l of $25 \mathrm{mM}$ solution), dATP ( $2 \mu$ l of $.05 \mathrm{mM}$ solution), digoxigenin-11-dUTP ( $2 \mu \mathrm{l}$; Boehringer-Mannheim), sterile water (3- 
Table I. Description of Cases

\begin{tabular}{rllr}
\hline Case & Age & Premortem neurologic evaluation & $\begin{array}{r}\text { Duration (onset of } \\
\text { rash to death) }\end{array}$ \\
\hline 318 & $6 \mathrm{mo}$ & seizures, papilledema & $10 \mathrm{~d}$ \\
430 & $9 \mathrm{mo}$ & no focal neurologic signs & $8 \mathrm{~d}$ \\
519 & $5 \mathrm{yr}$ & no focal neurologic signs & $3-4 \mathrm{~d}$ \\
527 & $1 \mathrm{yr}$ & no focal neurologic signs & $8 \mathrm{~d}$ \\
542 & $2.25 \mathrm{yr}$ & somnolence, hypertonia, bilateral & $4 \mathrm{~d}$ \\
& \multicolumn{3}{c}{ Babinski signs, hyperactive } \\
& deep tendon reflexes \\
\hline
\end{tabular}

$5 \mu \mathrm{l}$ ), and terminal transferase ( $1 \mu \mathrm{l})$ were added to $1 \mu \mathrm{l}$ of oligonucleotide $(200 \mathrm{nM})$ and incubated for $5 \mathrm{~min}$ at $37^{\circ} \mathrm{C}$. Slides were covered with parafilm and placed in a moist chamber at $37^{\circ} \mathrm{C}$ overnight. Slides were washed twice in $2 \times \mathrm{SSC}$ at room temperature for 10 minutes, $0.1 \times \mathrm{SSC}$ at $37^{\circ}$ for 20 minutes, then once with $0.1 \times \mathrm{SSC}$ at room temperature for $5 \mathrm{~min}$. Immunologic detection was accomplished with the Genius Non-radioactive Nucleic Acid Detection Kit (BoehringerMannheim). Sections were washed in Buffer 1 (100 mM Tris-HCL; $150 \mathrm{mM} \mathrm{NaCl} ; \mathrm{pH} 7.5$ ) for $1 \mathrm{~min}$. Slides were then incubated in Buffer 1 containing $2 \%$ normal lamb serum (GIBCO BRL, Gaithersburg, MD) and $0.3 \%$ Triton X-100 for $30 \mathrm{~min}$. Anti-digoxigenin antibody conjugate ( 25 nmoles) was diluted 1:500 and placed in Buffer 1 containing 2\% normal lamb serum and $0.3 \%$ Triton-X $100.100 \mu \mathrm{l}$ of this solution was placed onto each slide, covered with parafilm, and incubated in a humid chamber for $4 \mathrm{~h}$. Slides were washed for $10 \mathrm{~min}$ with shaking in Buffer 2 ( $100 \mathrm{mM}$ Tris-HCL, $100 \mathrm{mM} \mathrm{NaCl}, 50 \mathrm{mM} \mathrm{MgCl}$; pH 9.5). $500 \mu 1$ color solution $(45 \mu \mathrm{l}$ nitroblue tetrazolium, $35 \mu \mathrm{l}$ X-phosphate [5bromo-4-chloro-3-indoyl phosphate; Boehringer-Mannheim] with 2.4 mg levamisole [Sigma Chemical Co., St. Louis, MO] placed in $10 \mathrm{ml}$ Buffer 2) was placed on each slide, slides were covered with parafilm and incubated in a humid chamber in the dark overnight. Reaction was stopped by placing slides in Buffer 3 ( $10 \mathrm{mM}$ Tris-HCl, $1 \mathrm{mM}$ EDTA, $\mathrm{pH}$ 8.0). Slides were dehydrated in graded alcohols and mounted.

Immunoperoxidase staining. Representative slides were prepared for immunocytochemical staining, some of which had already been hybridized to measles virus as described above. Slides were deparaffinized, hydrated, and rinsed with tap water for $5 \mathrm{~min}$. Sections were incubated for $30 \mathrm{~min}$ in $0.3 \% \mathrm{H}_{2} \mathrm{O}_{2}$ in methanol, washed in $1 \times$ PBS for $20 \mathrm{~min}$, then blocked for $20 \mathrm{~min}$ with diluted normal rabbit blocking serum. Slides were incubated overnight at $4^{\circ} \mathrm{C}$ with anti-glial fibrillary acidic protein $(0.21 \mathrm{mg})$ or anti-ferritin $(6.8 \mu \mathrm{g})$. Slides were washed in $1 \times$ PBS for $10 \mathrm{~min}$, then incubated for $30 \mathrm{~min}$ with diluted biotinylated anti-goat antibody (Vectastain ABC, Vector Laboratories, Burlingame, CA) using $50 \mu \mathrm{l}$ of antibody stock with $150 \mu \mathrm{l}$ normal blocking serum and $10 \mathrm{ml}$ PBS. Slides were washed in $1 \times$ PBS for $10 \mathrm{~min}$, then incubated for 30 min with the Vectastain $A B C$ reagent. After a 10min wash in PBS, slides were incubated in peroxidase substrate (3,3'diaminobenzidine tetrahydrochloride [Sigma Chemical Co.]) for 2-7 $\mathrm{min}$ as a chromogen, then washed in tap water for $5 \mathrm{~min}$. Selected slides were counterstained with hematoxylin.

Reverse transcriptase-PCR-in situ hybridization. Deparaffinized tissue sections were rehydrated, digested with $50 \mu \mathrm{g} / \mathrm{ml}$ of proteinase $\mathrm{K}$ [Boehringer-Mannheim] for $10 \mathrm{~min}$ at $37^{\circ} \mathrm{C}$, post-fixed in $4 \%$ paraformaldehyde for $5 \mathrm{~min}$ then washed in PBS. Sections were then incubated with 20 units of RNAse-free DNase (Boehringer-Mannheim) at $37^{\circ} \mathrm{C}$ overnight. Slides were washed in PBS and dehydrated. Then $40 \mu \mathrm{l}$ of cDNA synthesis mixture $(50 \mathrm{mM}$ Tris- $\mathrm{HCL}, 6 \mathrm{mM} \mathrm{MgCl}, 10 \mathrm{mM}$ dithiothreitol, $100 \mathrm{mM} \mathrm{NaCl}, 200 \mu \mathrm{M}$ concentration of each dNTP [Boehringer-Mannheim], $25 \mu \mathrm{M}$ avian myeloblastosis virus reverse transcriptase [Boehringer-Mannheim] and 40 pmoles of an antisense measles virus-specific fusion protein primer ( $5^{\prime}$ to $3^{\prime}$ : CTTGAGAGCCTATGTTGTACG) and/or oligonucleotide primer $\mathrm{p}(\mathrm{dT}) 15$ [Boeh-
ringer-Mannheim]) was applied for $1 \mathrm{~h}$ at $42^{\circ} \mathrm{C}$. Slides were washed in PBS and dehydrated. For amplification of cDNA, $30 \mu \mathrm{l}$ of PCR reaction mixture $(300 \mu \mathrm{M}$ of each $\mathrm{dNTP}, 30 \mathrm{pM}$ of each fusion protein primer [upstream primer; 5' to 3': GGCATTTGAGGCAATCAGACA; and the downstream primer used in the cDNA synthesis mixture ], 5 units Taq DNA polymerase [Boehringer-Mannheim], $2.5 \mathrm{mM} \mathrm{MgCl} 2,10$ $\mathrm{mM}$ Tris- $\mathrm{HCl}, 50 \mathrm{mM} \mathrm{KCl}$ ) was placed on each slide under silanized coverslips at $62^{\circ} \mathrm{C}$ and sealed with nail polish. $15-25$ cycles of PCR was performed in a Biosycler Oven (Integrated Separation Systems, Natick, MA) using the following conditions: denaturation at $94^{\circ}$, annealing at $55^{\circ}$, extension at $72^{\circ} \mathrm{C}$, each for $30 \mathrm{~s}$. Coverslips were then removed and tissue was washed in PBS. After dehydration, amplified DNA was denatured in prehybridization solution (as above) and hybridized to a digoxigenin end-labeled sense fusion protein probe (since reverse transcriptase-PCR yields a double-stranded DNA product, antisense probes were not specifically required) at $45^{\circ} \mathrm{C}$ for $18 \mathrm{~h}$. A nonsense probe homologous to the lacZ' region in pUC and M13 plasmids was used as a control (Boehringer-Mannheim). Color development was performed as described above for in situ hybridization.

\section{Results}

Endothelial cell staining by in situ hybridization and RT-PCR in situ hybridization in acute fatal measles. In situ hybridization using the antisense oligonucleotide probe (detects fusion protein mRNA) revealed endothelial cell infection in 5 of the 5 cases of acute fatal measles studied (Fig. $1 A$ ). Other CNS cells were not positive. Sense probes (Fig. $1 B$ ) and nonsense probes in acute measles brains as well as antisense probes in normal, AIDS, and viral encephalitis brains, did not react with endothelial or other cells (data not shown).

To determine whether other brain parenchymal cells may be infected, but not detected by routine in situ hybridization, reverse transcriptase (RT)-PCR in situ hybridization was performed to increase the sensitivity of the assay. Endothelial cells were again positive in acute fatal measles without evidence of infection of other cells (Fig. $1 C$ ). Sensitivity was increased since the staining was somewhat darker and there was an increase in the numbers of endothelial cells staining positively as compared to the regular in situ hybridization technique. Nonsense probes were negative (Fig. $1 D$ ) as were antisense probes of the three control brains stated above (data not shown). Additionally, immunohistochemical staining was performed for both measles virus antigen and the serum proteins albumin and haptoglobin to determine the integrity of the blood-brain barrier. In the cases of acute fatal measles, there was evidence of parenchymal uptake of albumin and/or haptoglobin; this was most dramatic in the areas where the endothelial cells stained most frequently for measles virus antigen (data not shown).

Reactive microgliosis. Immunocytochemical staining of brains from acute measles patients was performed for ferritin and glial fibrillary acidic protein (GFAP) as an indication of microglial or astrocytic reactivity respectively $(20,21)$. The amount of GFAP staining was not different between measles and controls (data not shown). The amount of ferritin staining was increased in acute measles (Fig. $1 E$ ) compared with a normal control brain (Fig. $1 F$ ), indicative of a reactive microgliosis.

\section{Discussion}

These studies have shown that in acute fatal measles, brain endothelial cells are frequently infected. Microgliosis, while 

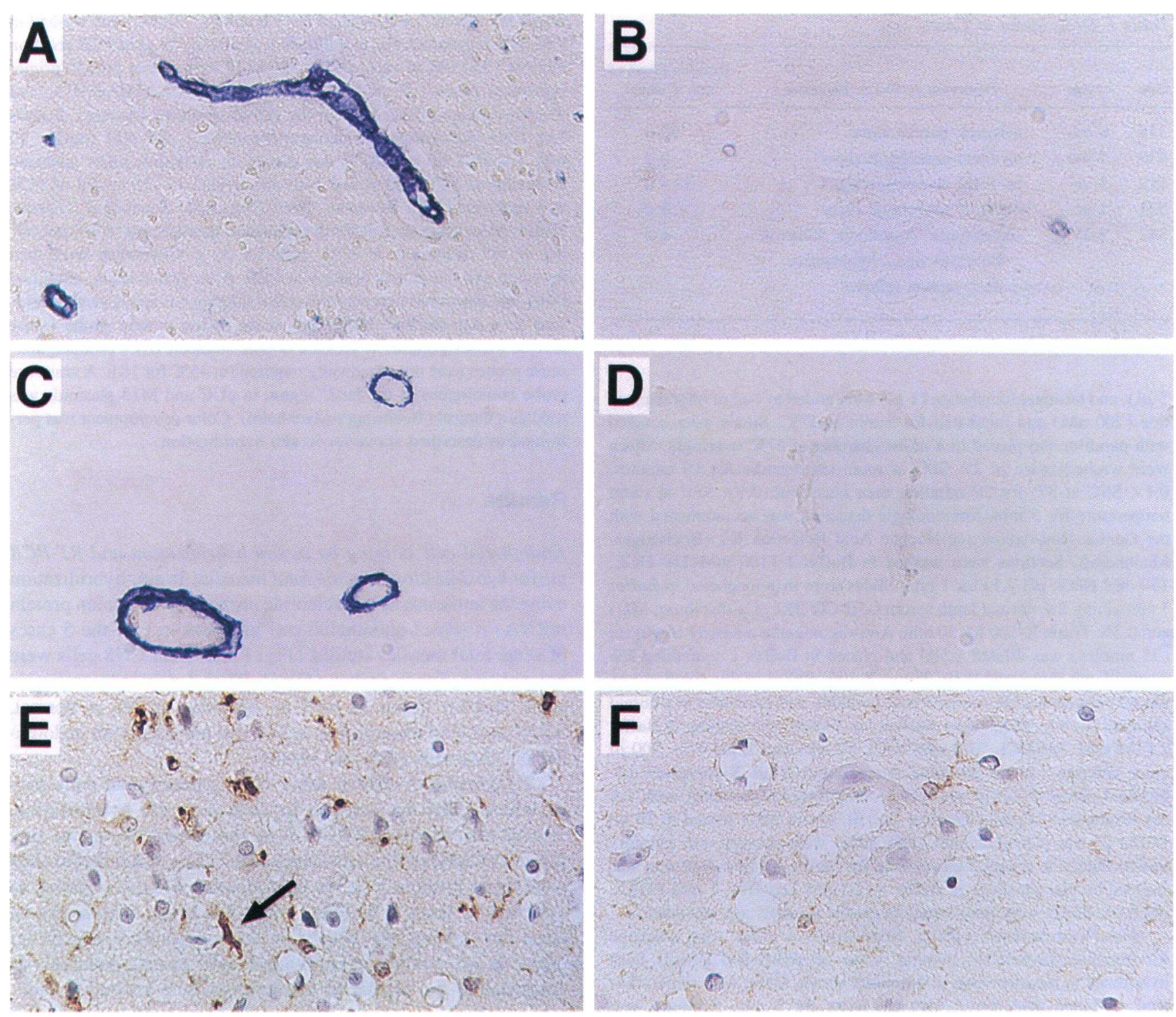

Figure 1. $(A$ and $B)$ Endothelial cell staining in the brain of a patient with acute fatal measles by in situ hybridization using a measles virus probe ( $A$, antisense probe; $B$, sense probe). ( $C$ and $D$ ) Endothelial cell staining in the brain of an additional patient with acute fatal measles by RT-PCR in situ hybridization ( $C$, sense probe; $D$, nonsense probe). $(E$ and $F$ ) Increased ferritin staining in acute fatal measles $(E)$, as compared with normal staining in a control brain $(F) . \times 200$.

nonspecific, is indicative of a CNS insult and is known to be present in various types of encephalopathies (22-24). Leakage of the intravascular molecules haptoglobin and albumin is suggestive of an impaired blood-brain barrier. Since endothelial cell infection with measles virus in vitro has been shown to alter such endothelial cell functions as membrane permeability and cytokine expression, these observations may provide clues to the pathogenesis of some acute and postmeasles CNS complications $(11,25)$.

These studies suggest that in cases of SSPE, initial virus entry into the CNS may occur at the time of acute infection. We would postulate that parenchymal cells adjacent to infected endothelial cells may occasionally become infected initiating a slowly progressive process that leads to SSPE. That this is unusual is underscored by our failure to detect other infected
CNS cells in our cases of acute fatal measles. Some reports have indicated that endothelial cells may continue to be infected in the late stages of SSPE (26).

In summary, measles virus infection of CNS endothelial cells is common in young children with acute fatal measles. Infection of these cells may contribute to the morbidity and mortality of measles by compromising the function of the bloodbrain barrier and by providing a route of entry for virus into the brain parenchyma.

\section{Acknowledgments}

This work has been supported by research grants AI-23047 and training grant NS- 07000 from the National Institutes of Health and by a research grant from the National Multiple Sclerosis Society. 


\section{References}

1. Soilu-Hanninen, M., J. P. Eralinna, V. Hukkanen, M. Roytta, A. A. Salmi, and R. Salonen. 1994. Semliki Forest virus infects mouse brain endothelial cells and causes blood-brain barrier damage. J. Virol. 68:6291-6298.

2. Laegreid, W. W., T. G. Burrage, M. Stone-Marschat, and A. Skowronek. 1992. Electron microscopic evidence for endothelial cell infection by African horsesickness virus. Vet. Pathol. 29:554-556.

3. Edington, N., B. Smyth, and L. Griffiths. 1991. The role of endothelial cell infection in the endometrium, placenta and foetus of equid herpesvirus 1 (EHV1) abortions. J. Comp. Pathol. 104:379-387.

4. Wiley, C. A., and J. A. Nelson. 1988. Role of human immunodeficiency virus and cytomegalovirus in AIDS encephalitis. Am. J. Pathol. 133:73-81.

5. Sanchez-Lanier, M., L. E. Davis, K. S. Blisard, B. M. Woodfin, J. M. Wallace, and L. S. Caskey. 1991. Influenza A virus in the mouse: hepatic and cerebral lesions in a Reye's syndrome-like illness. Int. J. Exp. Pathol. 72:489 500.

6. Ressetar, H. G., H. D. Webster, and G. L. Stoner. 1992. Brain vascular endothelial cells express JC virus large tumor antigen in immunocompetent and cyclophosphamide-treated hamsters. Proc. Natl. Acad. Sci. USA. 89:8170-8174.

7. Chakrabarti, R., F. M. Hofman, R. Pandey, L. E. Mathes, and P. RoyBurman. 1994. Recombination between feline exogenous and endogenous retroviral sequences generates tropism for cerebral endothelial cells. Am. J. Pathol. 144:348-358.

8. Park, B. H., E. Lavi, K. J. Blank, and G. N. Gaulton. 1993. Intracerebral hemorrhages and syncytium formation induced by endothelial cell infection with a murine leukemia virus. J. Virol. 67:6015-6024.

9. Park, B. H., E. Lavi, A. Stieber, and G. N. Gaulton. 1994. Pathogenesis of cerebral infarction and hemorrhage induced by a murine leukemia virus. $L a b$. Invest. 70:78-85.

10. Csonka E., P. I. Bayer, K. Buki, and G. Varady. 1990. Influence of the measles virus on the proliferation and protein synthesis of aortic endothelial and smooth muscle cells. Acta. Microbiol. Hung. 37:193-200.

11. Moench, T. R., D. E. Griffin, C. R. Obriecht, A. J. Vaisberg, and R. T Johnson. 1988. Acute measles in patients with and without neurological involvement: distribution of measles virus antigen and RNA. J. Infect. Dis. 158:433442.

12. Oyanagi, S., L. B. Rorke, M. Katz, and H. Koprowski. 1971. Histopathology and electron microscopy of three cases of subacute sclerosing panencephalitis (SSPE). Acta Neuropathol. (Berl.). 63:58-73.
13. Connolly, J. H., I. V. Allen, L. J. Hurowitz, and J. H. D. Millar. 1967. Measles virus antibody and antigen in subacute sclerosing panencephalitis. Lancet. I:542-544.

14. Sluga, W., H. Budka, K. Jellinger, and E. Pichler. 1975. SSPE-like inclusion body disorder in treated childhood leukemia. Acta Neuropathol. Suppl. (Berl.). 6:267-272.

15. Hughes, I., M. E. M. Jenney, R. W. Newton, D. J. Morris, and P. E. Klapper. 1993. Measles encephalitis during immunosuppressive treatment for acute lymphoblastic leukemia. Arch. Dis. Child. 68:775-778.

16. Johnson, R. T., D. E. Griffin, R. L. Hirsch, J. S. Wolinsky, S. Roedenbeck, I. Lindo de Soriano, and A. Vaisberg. 1984. Measles encephalomyelitis-clinical and immunological studies. N. Engl. J. Med. 310:137-141.

17. Miller, D. L. 1964. Frequency of complications of measles. Br. Med. J. 2:75-78.

18. McLean, D. M., J. M. Best, P. A. Smith, R. P. B. Larke, and G. A. McNaughton. 1966. Viral infections of Toronto children during 1965: measles encephalitis and other complications. Can. Med. Assoc. J. 94:905-910.

19. Johnson, R. T., R. L. Hirsch, D. E. Griffin, J. S. Wolinsky, S. Roedenbeck, I. Lindo de Soriano, and A. Vaisberg. 1981. Clinical and immunological studies of measles encephalitis. Trans. Am. Neurol. Assoc. 106:1-4.

20. Connor, J. R., S. L. Menzies, S. M. St. Martin, and E. J. Mufson. 1990. Cellular distribution of transferrin, ferritin, and iron in normal and aged human brains. J. Neurosci. Res. 27:595-611.

21. Estes, M. L., R. M. Ransohoff, J. T. McMahon, B. S. Jacobs, and B. P. Barna. 1990. Characterization of adult human astrocytes derived from explant culture. J. Neurosci. Res. 27:697-705.

22. Gelman, B. B. 1993. Diffuse microgliosis associated with cerebral atrophy in the acquired immunodeficiency syndrome. Ann. Neurol. 34:65-70.

23. Hurtrel, B., L. Chakrabarti, M. Hurtrel, and L. Montagnier. 1993. Target cells during early SIV encephalopathy. Res. Virol. 144:41-46.

24. Yamasaki, H., T. Umemura, M. Goryo, and C. Itakura. 1991. Chronic lesions of thrombo-embolic meningo-encephalomyelitis in calves. J. Comp. Pathol. 105:303-312.

25. Gerson, S. L., H. M. Friedman, and D. B. Cines. 1985. Viral infection of vascular endothelial cells alters production of colony-stimulating activity. J. Clin. Invest. 76:1382-1390.

26. Kirk, J., A. L. Zhou, S. McQuaid, S. L. Cosby, and I. V. Allen. 1991. Cerebral endothelial cell infection by measles virus in subacute sclerosing panencephalitis: ultrastructural and in situ hybridization evidence. Neuropathol. Appl. Neurobiol. 17:289-297. 